\begin{tabular}{llllll} 
& ISRA (India) $=\mathbf{3 . 1 1 7}$ & SIS (USA) & $=\mathbf{0 . 9 1 2}$ & ICV (Poland) & $=\mathbf{6 . 6 3 0}$ \\
Impact Factor: & ISI (Dubai, UAE) $=\mathbf{0 . 8 2 9}$ & PUHL (Russia) $=\mathbf{0 . 1 5 6}$ & PIF (India) & $=\mathbf{1 . 9 4 0}$ \\
& GIF (Australia) $=\mathbf{0 . 5 6 4}$ & ESJI (KZ) & $=\mathbf{8 . 7 1 6}$ & IBI (India) & $=\mathbf{4 . 2 6 0}$ \\
& JIF & $\mathbf{1 . 5 0 0}$ & SJIF (Morocco) $=\mathbf{5 . 6 6 7}$ & OAJI (USA) & $\mathbf{0 . 3 5 0}$ \\
\hline
\end{tabular}

\section{SOI: $\underline{1.1 / \mathrm{TAS}}$ DOI: $10.15863 / \mathrm{TAS}$ International Scientific Journal Theoretical \& Applied Science}

\author{
p-ISSN: 2308-4944 (print) e-ISSN: 2409-0085 (online) \\ Year: 2019 Issue: $05 \quad$ Volume: 73
}

Published: $30.05 .2019 \quad \underline{\text { http://T-Science.org }}$
QR - Issue

QR - Article
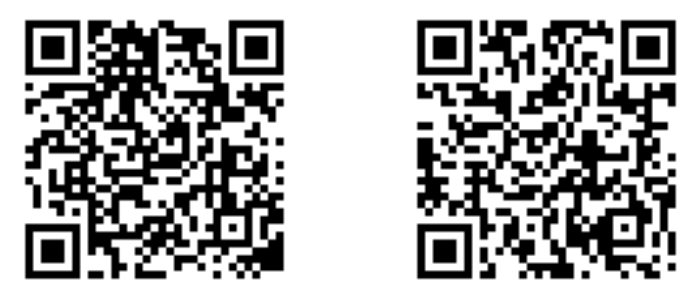

Abdulaziz Abdushukur ugli Abdurazzakov

Student,

Tashkent State Institute of Oriental Studies

Nodir Rakhmonqulovich Karimov

$\mathrm{PhD}$ student

Tashkent State Institute of Oriental Studies

\title{
SOME BRIEF INFORMATION ON AL-SIHAH AL-SITTA
}

Abstract: This article gives brief information on al-kutub al-sitta which means six books containing collections of hadith (sayings or acts of the Islamic prophet Muhammad) compiled by six Sunni Muslim scholars in the ninth century CE. They are sometimes referred to as Al-Sihah al-Sittah, which translates as "The Authentic Six". It also covers some data on the authors of famous six books.

Key words: al-kutub al-sitta, hadith, Bukhari, Muslim, Abu Dawud, Tirmidhi.

Language: English

Citation: Abdurazzakov, A. A., \& Karimov, N. R. (2019). Some brief information on Al-Sihah Al-Sitta. ISJ Theoretical \& Applied Science, 05 (73), 611-620.

Soi: http://s-o-i.org/1.1/TAS-05-73-96 Doi: crossef https://dx.doi.org/10.15863/TAS.2019.05.73.96

\section{Introduction}

A very important source of Islamic law, not to say interpretation of the Qur'an, comes from the traditional saying of the Prophet and those close to him. These have been collected and are called hadith. Many collections (ahadith, sing. hadith) had been made during the third century/ninth century, but six work become recognize as authoritative in Sunni Islam, especially the Sahih al-Bukhari and and the Sahih Muslim. The adjective Sahih actually means accredited: the other four are also highly esteemed, but is allowed by the Muslim and the other texts are much quoted and have became highly regarded, considered second to the Qur'an itself as sources of authority for the laws and customs of Islam. The al-kutub al-sitta ('the six books) comprise the canonical hadith literature and, as such, form the main sources for traditional law. The Muwatta of Imam Malik is not really a collection of ahadith in the sense of the legal traditions for its own sake, but includes them specifically as a guide to law, and so is a useful source also. Some Muslim authorities include it instead of the Sunan of Ibn Maja among the six canonical collections.

\section{Main part}

The Kutub al-Sittah are six (originally five) books containing collections of hadith (sayings or acts of the Islamic prophet Muhammad) compiled by six Sunni Muslim scholars in the ninth century CE. They are sometimes referred to as Al-Sihah al-Sittah, which translates as "The Authentic Six". They were first formally grouped and defined by Ibn alQaisarani in the 11th century, who added Sunan ibn Majah to the list[25, p.36; 2,p.86; 34, p.47]. Since then, they have enjoyed near-universal acceptance as part of the official canon of Sunni Islam.

Not all Sunni Muslim jurisprudence scholars agree on the addition of Ibn Majah. In particular, the Malikis and Ibn al-Athir consider al-Mawatta' to be the sixth book. The reason for the addition of Ibn Majah's Sunan is that it contains many Hadiths which do not figure in the other five, whereas all the Hadiths in the Muwatta' figure in the other Sahih books [27, p.39].

Sunni Muslims view the six major hadith collections as their most important, though the order of authenticity varies between Madhhabs [5, p.36]

1. Sahih Bukhari, collected by Imam Bukhari (d. $256 \mathrm{AH}, 870 \mathrm{CE}$ ), includes 7,275 ahadith

2. Sahih Muslim, collected by Muslim b. alHajjaj (d. 261 AH, 875 CE), includes 9,200 ahadith 


\begin{tabular}{llllll} 
& ISRA (India) $=\mathbf{3 . 1 1 7}$ & SIS (USA) $=\mathbf{0 . 9 1 2}$ & ICV (Poland) & $\mathbf{= 6 . 6 3 0}$ \\
Impact Factor: & ISI (Dubai, UAE) $=\mathbf{0 . 8 2 9}$ & PUHЦ (Russia) $=\mathbf{0 . 1 5 6}$ & PIF (India) & $=\mathbf{1 . 9 4 0}$ \\
& GIF (Australia) $=\mathbf{0 . 5 6 4}$ & ESJI (KZ) & $\mathbf{8 . 7 1 6}$ & IBI (India) & $=\mathbf{4 . 2 6 0}$ \\
& JIF & $\mathbf{1 . 5 0 0}$ & SJIF (Morocco) $=\mathbf{5 . 6 6 7}$ & OAJI (USA) & $\mathbf{0 . 3 5 0}$ \\
\hline
\end{tabular}

3. Sunan Abu Dawood, collected by Abu Dawood (d. 275 AH, 888 CE), includes 4,800 ahadith 4. Jami al-Tirmidhi, collected by alTirmidhi (d. 279 AH, 892 CE), includes 3,956 ahadith

5. Sunan al-Sughra, collected by al-Nasa'i (d. $303 \mathrm{AH}, 915 \mathrm{CE}$ ), includes 5,270 ahadith

6. Either:

7. Sunan ibn Majah, collected by Ibn Majah (d. $273 \mathrm{AH}, 887 \mathrm{CE}$ ), over 4,000 ahadith

8. Muwatta Malik, collected by Imam Malik (d. $179 \mathrm{AH}, 795 \mathrm{CE}), 1,720$ ahadith[2, p.66] .

The first two, commonly referred to as the Two Sahihs as an indication of their authenticity, contain approximately seven thousand hadiths altogether if repetitions are not counted, according to Ibn Hajar[27, p.94]

According to the Cambridge History of Iran:[18, p.36]"After this period commences the age of the authors of the six canonical collections of Sunni hadith, all of whom were Persian, except Imam Malik. The authors of the six collections are as follows:

1. Muhammad b. Isma'il al-Bukhari, the author of the Sahih Bukhari, which he composed over a period of sixteen years. Traditional sources quote Bukhari as saying that he did not record any hadith before performing ablution and praying. Bukhari died near Samarqand in 256/869-70

2. Muslim b. Hajjaj al-Naishapuri, who died in Nishapur in 261/874-5 and whose Sahih Muslim is second in authenticity only to that of Bukhari. Some scholars rate the authenticity of Sahih Muslim more than Sahih Bukhari

3. Abu Dawood Sulaiman b. Ash'ath alSijistani, a Persian but of Arab descent, who died in 275/888-9.

4. Muhammad b. 'Isa al-Tirmidhi, the author of the well-known as Sunan al-Tirmidhi, who was a student of Bukhari and died in 279/892-3.

5. Abu 'Abd al-Rahman al-Nasa'i, who was from Khurasan and died in 303/915-16.

6. Ibn Majah al-Qazwini, who died in 273/8867.

7. Malik was born the son of Anas ibn Malik (not the Sahabi) and Aaliyah bint Shurayk al-Azdiyya in Medina circa 711. His family was originally from the al-Asbahi tribe of Yemen, but his great grandfather Abu 'Amir relocated the family to Medina after converting to Islam in the second year of the Hijri calendar, or $623 \mathrm{CE}$. According to AlMuwatta, he was tall, heavyset, imposing of stature, very fair, with white hair and beard but bald, with a huge beard and blue eyes [23, p.36]. In chronological order his work was compiled even earlier than Sahih Bukhari, therefore Al-Muwatta is highly regarded in Islamic literature.

Sahihi Bukhari
Șahịị al-Bukhārī also known as Bukhari Sharif is one of the Kutub al-Sittah (six major hadith collections) of Sunni Islam. These prophetic traditions, or hadith, were collected by the Muslim scholar Muhammad al-Bukhari. It was completed around 846 AD / 232 AH. Sunni Muslims view this as one of the two most trusted collections of hadith along with Sahih Muslim [15, p.66;14, p.37]. The Arabic word sahih translates as authentic or correct [13, p.48]. Sahih al-Bukhari, together with Sahih Muslim is known as Sahihayn.

According to Ibn al-Salah the book is called: alJaami' al-Sahih al-Musnad al-Mukhtasar min Umuri Rasooli-llahi wa sunanihi wa Ayyaamihi (The Abridged Collection of Authentic Hadith with Connected Chains regarding Matters Pertaining to the Prophet, His practices and His Times)[4, p.25]Ibn Hajar al-Asqalani mentioned the same title, replacing the word umur (English: matters) with hadith[16, p.36].

Al-Bukhari traveled widely throughout the Abbasid Caliphate from the age of 16, collecting those traditions he thought trustworthy. It is reported that al-Bukhari devoted 16 years to sifting the hadiths he included in his Sahih from a collection of nearly 600,000 narrations. Sources differ on the exact number of hadiths in Bukhari's Sahih, depending on whether a hadith is defined as a Prophetic tradition or a narration of that tradition. Experts, in general, have estimated the number of full-isnad narration at 7,397, and without considerations to repetitions or different versions of the same report, the number of Prophetic traditions reduces to approximately 2,6021[6, p.36]. At the time when Bukhari saw the earlier works and conveyed them, he found them, in their presentation, combining between what would be considered sahih (correct) and hasan (good) and that many of them included da'if (weak) hadith. This aroused his interest in compiling hadith whose authenticity was beyond doubt. What further strengthened his resolve was something his teacher, hadith scholar Ishaq ibn Ibrahim alHanthalee - better known as Ishaq Ibn Rahwayh - had told him. "We were with Ishaq Ibn Rahwayh who said, 'If only you would compile a book of only authentic narrations of the Prophet.' This suggestion remained in my heart so I began compiling the Sahih." Bukhari also said, "I saw the Prophet in a dream and it was as if I was standing in front of him. In my hand was a fan with which I was protecting him. I asked some dream interpreters, who said to me, 'You will protect him from lies.' This is what compelled me to produce the Sahih[17, p.93]."

The book covers almost all aspects of life in providing proper guidance of Islam such as the method of performing prayers and other actions of worship directly from the Islamic 


\begin{tabular}{llllll} 
& ISRA (India) $=\mathbf{3 . 1 1 7}$ & SIS (USA) $=\mathbf{0 . 9 1 2}$ & ICV (Poland) & $\mathbf{= 6 . 6 3 0}$ \\
Impact Factor: & ISI (Dubai, UAE) $=\mathbf{0 . 8 2 9}$ & PUHЦ (Russia) $=\mathbf{0 . 1 5 6}$ & PIF (India) & $=\mathbf{1 . 9 4 0}$ \\
& GIF (Australia) $=\mathbf{0 . 5 6 4}$ & ESJI (KZ) & $\mathbf{8 . 7 1 6}$ & IBI (India) & $=\mathbf{4 . 2 6 0}$ \\
& JIF & $\mathbf{1 . 5 0 0}$ & SJIF (Morocco) $=\mathbf{5 . 6 6 7}$ & OAJI (USA) & $\mathbf{0 . 3 5 0}$ \\
\hline
\end{tabular}

prophet, Muhammad. Bukhari finished his work around 846/232 $\mathrm{AH}$, and spent the last twenty-four years of his life visiting other cities and scholars, teaching the hadith he had collected. In every city that Bukhari visited, thousands of people would gather in the main mosque to listen to him recite traditions. In reply to Western academic doubts as to the actual date and authorship of the book that bears his name, scholars point out that notable hadith scholars of that time, such as Ahmad ibn Hanbal (855 CE/241 $\mathrm{AH})$, Yahya ibn Ma'in (847 CE/233 AH), and Ali ibn al-Madini(848 CE/234 AH), accepted the authenticity of his book[14, p.93] and that the collection's immediate fame makes it unlikely that it could have been revised after the author's death without historical record.

During this period of twenty-four years, alBukhari made minor revisions to his book, notably the chapter headings. Each version is named by its narrator. According to Ibn Hajar al-Asqalani in his book Nukat, the number of hadiths in all versions is the same. The most famous one today is the version narrated by al-Firabri (d. $932 \mathrm{CE} / 320 \mathrm{AH}$ ), a trusted student of Bukhari. Al-Khatib al-Baghdadi in his book History of Baghdad quoted Firabri as saying: "About seventy thousand people heard Sahih Bukhari with me".

Firabri is not the only transmitter of Sahih alBukhari. There were many others that narrated that book to later generations, such as Ibrahim ibn Ma'qal (d. $907 \mathrm{CE} / 295 \mathrm{AH}$ ), Hammad ibn Shaker (d. 923 CE/311 AH), Mansur Burduzi (d. 931 CE/319 AH) and Husain Mahamili (d. 941 CE/330 AH). There are many books that noted differences between these versions, the best known being Fath al-Bari.

Amin Ahsan Islahi, the Islamic scholar, has listed three outstanding qualities of Sahih alBukhari:[39, p.36]

1. Quality and soundness of the chain of narrators of the selected ahādīth. Muhammad alBukhari has followed two principal criteria for selecting sound narratives. First, the lifetime of a narrator should overlap with the lifetime of the authority from whom he narrates. Second, it should be verifiable that narrators have met with their source persons. They should also expressly state that they obtained the narrative from these authorities. This is a stricter criterion than that set by Muslim ibn al-Hajjaj.

2. Muhammad al-Bukhari accepted the narratives from only those who, according to his knowledge, not only believed in Islam but practiced its teachings. Thus, he has not accepted narratives from the Murjites.

3. The particular arrangement and ordering of chapters. This expresses the profound knowledge of the author and his understanding of the religion. This has made the book a more useful guide in understanding of the religious disciplines.

The Orientalist Manjana said in Cambridge in 1936 CE that the oldest manuscript he had come across up to that point was written in $984 \mathrm{CE} / 370 \mathrm{AH}$, according to the narration of al-Mirwazi from alFarbari[40, p.174].

Ibn al-Salah said: "The first to author a Sahih was Bukhari, Abū 'Abd Allāh Muhammad ibn Ismā'̄il al-Ju'fī, followed by Abū al-Husayn Muslim ibn al-Ḥajjāj an-Naysābūrī al-Qushayrī, who was his student, sharing many of the same teachers. These two books are the most authentic books after the Qur'ān. As for the statement of Al-Shafi' ${ }^{\prime} \mathrm{i}$, who said "I do not know of a book containing knowledge more correct than Malik's book," - others mentioned it with a different wording - he said this before the books of Bukhari and Muslim. The book of Bukhari is the more authentic of the two and more useful."[4]

Ibn Hajar al-Asqalani quoted Abu Ja far al'Uqailee as saying, "After Bukhari had written the Sahih, he read it to Ali ibn al-Madini, Ahmad ibn Hanbal, Yahya ibn Ma'in as well as others. They considered it a good effort and testified to its authenticity with the exception of four hadith. Al'Uqailee then said that Bukhari was actually correct regarding those four hadith." Ibn Hajar then concluded, "And they are, in fact, authentic[41, p.36]."

Ibn al-Salah said in his Muqaddimah ibn alȘalāh fì 'Ulūm al-Hadīth: "It has been narrated to us that Bukhari has said, 'I have not included in the book al-Jami' other than what is authentic and I did not include other authentic hadith for the sake of brevity."' In addition, al-Dhahabi said, "Bukhari was heard saying, 'I have memorized one hundred thousand authentic hadith and two hundred thousand which are less than authentic[42.p.37]."'

At least one famous ahaad (solitary) hadith in Bukhari, regarding women's leadership[43, p.56], based upon its content and its hadith narrator (Abu Bakr), is believed by some authors to be inauthentic. Shehadeh uses gender theory to critique the hadith[44, p.69], while Farooq believes that such hadiths are inconsistent with reforming Islam[45, p.39]. Affi and Affi also apply contemporary interpretations to Shariah law in discussing the hadith[46, p.65].

Another hadith ("Three things bring bad luck: house, woman, and horse."), reported by Abu Hurairah, has been criticized by Fatema Mernissi for being reported out of context and without any further clarification in Bukhari's collection. The clarification is given in a hadith reported by Aisha in Imam Zarkashi's (1344-1392) hadith collection: "...He [Abu Hurairah] came into our house when the Prophet was in the middle of a sentence. He only heard the end of 


\begin{tabular}{llllll} 
& ISRA (India) $=\mathbf{3 . 1 1 7}$ & SIS (USA) $=\mathbf{0 . 9 1 2}$ & ICV (Poland) & $\mathbf{= 6 . 6 3 0}$ \\
Impact Factor: & ISI (Dubai, UAE) $=\mathbf{0 . 8 2 9}$ & PUHЦ (Russia) $=\mathbf{0 . 1 5 6}$ & PIF (India) & $=\mathbf{1 . 9 4 0}$ \\
& GIF (Australia) $=\mathbf{0 . 5 6 4}$ & ESJI (KZ) & $\mathbf{8 . 7 1 6}$ & IBI (India) & $=\mathbf{4 . 2 6 0}$ \\
& JIF & $\mathbf{1 . 5 0 0}$ & SJIF (Morocco) $=\mathbf{5 . 6 6 7}$ & OAJI (USA) & $\mathbf{0 . 3 5 0}$ \\
\hline
\end{tabular}

it. What the Prophet said was: 'May God refute the Jews; they say three things bring bad luck: house, woman, and horse."' This case raises the question of whether other hadith in Bukhari have been reported incompletely and lacking proper context[47, p.95]. However, Abu Huraira was not the only contemporary of Muhammad to have reported this hadith.

Certain Prophetic medicine and remedies espoused in Bukhari, such as cupping, have been noted for being unscientific[48, p.93]. Sunni scholar Ibn Hajar al-Asqalani, on the basis of contrary archaeological evidence, criticised the hadith[50, p.146] which claimed that Adam's height was 60 cubits and human height has been decreasing ever since[51, p.69].

Ibn al-Salah also said: "The number of hadith in his book, the Sahih, is 7,275 hadith, including hadith occurring repeatedly. It has been said that this number excluding repeated hadith is 2,230[52.p.68]." This is referring to those hadith which are musnad [53, p39], those from the Companions originating from Muhammad which are authentic[55, p.67].

Several detailed commentaries on this collection have been written, estimated to number around 400[54, p.96], such as:

One of the most important aspects in Sahih alBukhari is tarjamah al-bab[15, p.58] or giving name of the chapter. Many great scholars adopted a common saying: "The Fiqh of Bukhari in His Chapters". Not many scholars have commented on this aspect except Hafiz Ibn Hajar Asqalani and a few others. Shah Waliyullah Muhadith Dehlawi had mentioned 14 usul (methods) to understand Abwab wa Tarajim, then added by Hind Maulana Shaykh Mahmud Hasan Ad-Deobandi to make it 15 usul. A study conducted by Syaikhul Hadith Maulana Muhammad Zakariyya had found as many as 70 usul. He wrote specifically about Tarajim Saheeh Al-Bukhari in his book, Al-Abwab wa At-Tarajim li Shahih Al-Bukharip[56, p.43; 57, p.92].

In 2019, the Arabic Virtual Translation Center in New York translated and published the first complete English translation of Sahih Al-Bukhari with full sanad and commentary. This work, titled Encyclopedia of Sahih Al-Bukhari, includes explanatory notes, a glossary of every term, and biographies of all characters.

Sahih al-Bukhari was originally translated into English by Muhammad Muhsin Khan under the title "The Translation of the Meanings of Sahih Al Bukhari Arabic English" in nine volumes [58, p.65]. The text used for this work is Fath Al-Bari, published by the Egyptian Press of Mustafa Al-Babi Al-Halabi in 1959. It is published by Al Saadawi Publications and Dar-us-Salam and is included in the USCMSA Compendium of Muslim Texts [59, p.36]. Large numbers of selected hadith from it have been translated by Muhammad Ali and Thomas Cleary.

\section{Sahih Muslim}

Sahih Muslim is one of the Kutub al-Sittah (six major hadith collections) in Sunni Islam.[66, p.36].It is highly acclaimed by Sunni Muslims [67, p.94] as well as Zaidi Shia Muslims.It is considered the second most authentic hadith collection after Sahih alBukhari. It was collected by Muslim ibn al-Hajjaj, also known as Imam Muslim[65, p.69]. Sahih Muslim, together with Sahih al-Bukhari is termed as Sahihayn.

The collector of the Sahih Muslim, Muslim ibn al-Hajjaj, was born into a Persianfamily in $204 \mathrm{AH}(817 / 18 \mathrm{CE}) \quad$ in Nishapur (in modernday Iran) and died in $261 \mathrm{AH}(874 / 75 \mathrm{CE})$ in the city of his birth. He traveled widely to gather his collection of ahadith (plural of hadith), including to areas now in Iraq, the Arabian Peninsula, Syria and Egypt.

Out of 300,000 hadith which he evaluated, approximately 4,000 were extracted for inclusion into his collection based on stringent acceptance criteria. Each report in his collection was checked and the veracity of the chain of reporters was painstakingly established. Sunni Muslims consider it the second most authentic hadith collection, after Sahih alBukhari. Sahih Muslim is divided into 43 books, containing a total of 9200 narrations. However, it is important to realize that Muslim ibn al-Hajjaj never claimed to collect all authentic traditions as his goal was to collect only traditions that all Muslims should agree on about accuracy.

According to Munthiri, there are a total of 2,200 hadiths (without repetition) in Sahih Muslim. According to Muhammad Amin[70, p.36], there are 1,400 authentic hadiths that are reported in other books, mainly the six major hadith collections.

Many Muslims regard this collection as the second most authentic of the six major hadith collections[71, p.36], containing only sahih hadith, an honor it shares only with Sahih al-Bukhari, both being referred to as the Two Sahihs. Shia Muslims dismiss some of its contents as fabrications or untrustworthy due to the questionable reliability of some narrators.

Despite the book's high stature, and the consensus of scholars on that it is the second most valid categorized book of Hadith, after Sahih alBukhari, it is agreed upon that this does not mean that every element in it is true, in comparison to other Hadith books, but means that the book as a whole is valid. Such as the preference of Sahih al-Bukhari to Sahih Muslim, which does not mean that every Hadith in Sahih al-Bukhari is more valid than every Hadith in Sahih Muslim, but that the total of what is contained Sahih al-Bukhari is more valid than the total of what is contained in Sahih Muslim, and likewise, the 


\begin{tabular}{llllll} 
& ISRA (India) $=\mathbf{3 . 1 1 7}$ & SIS (USA) $=\mathbf{0 . 9 1 2}$ & ICV (Poland) & $\mathbf{= 6 . 6 3 0}$ \\
Impact Factor: & ISI (Dubai, UAE) $=\mathbf{0 . 8 2 9}$ & PUHЦ (Russia) $=\mathbf{0 . 1 5 6}$ & PIF (India) & $=\mathbf{1 . 9 4 0}$ \\
& GIF (Australia) $=\mathbf{0 . 5 6 4}$ & ESJI (KZ) & $\mathbf{8 . 7 1 6}$ & IBI (India) & $=\mathbf{4 . 2 6 0}$ \\
& JIF & $\mathbf{1 . 5 0 0}$ & SJIF (Morocco) $=\mathbf{5 . 6 6 7}$ & OAJI (USA) & $\mathbf{0 . 3 5 0}$ \\
\hline
\end{tabular}

validity of a certain Hadith form the two books of Hadith, over Hadith from other Sahih books, can not be inferred except after the correctness of that particular Hadith is shown [72, p.36].

Amin Ahsan Islahi, the noted Islamic scholar, has summarized some unique features of Sahih Muslim[73, p.43]:

1. Muslim ibn al-Hajjaj recorded only such narratives as were reported by two reliable successors from two Sahabah (Companions of Muhammad) which subsequently travelled through two independent unbroken isnāds consisting of sound narrators. Muhammad al-Bukhari has not followed such a strict criterion.

2. Scientific arrangement of themes and chapters. The author, for example, selects a proper place for the narrative and, next to it, puts all its versions. Muhammad al-Bukhari has not followed this method (he scatters different versions of a narrative and the related material in different chapters).

3. Muslim ibn al-Hajjaj informs us whose wordings among the narrators he has used. For example, he says: haddathanā fulān wa fulān wallafz lifulān (A and B has narrated this hadīth to us and the wording used here is by A). Similarly he mentions whether, in a particular hadith, the narrators have differed over the wordings even over a single letter of zero semantic significance. He also informs the readers if narrators have differed over a specific quality, surname, relation or any other fact about a narrator in the chain.

Further information: Sharh Sahih Muslim

1. Siyanah Sahih Muslim by Ibn al-Salah, of which only the beginning segment remains

2. Al Minhaj Be Sharh Sahih Muslim by AlNawawi.

3. Fath al-Mulhim by Shabbir Ahmad Usmani.

4. Takmilat Fath al-Mulhim by Muhammad Taqi Usmani.

5. Summarized Sahih Muslim by Abd-alHamid Siddiqui. The text is used in the USCMSA Compendium of Muslim Texts.

6. Sharh Sahih Muslim by Allama Ghulam Rasool Saeedi

7. Tafsir al-gharib ma fi al-Sahihayn by AlHumaydī Translations of commentaries of Sahih Muslims are available in numerous languages including English, Urdu, Bangla, Tamil, and Bosnian[74, p.26].

\section{Sunan Abu Dawood}

Sunan Abu Dawood is one of the Kutub alSittah (six major hadith collections), collected by Abu Dawood [75, p.56].

Abu Dawood compiled twenty-one books related to Hadith and preferred those ahadith which were supported by the example of the companions of
Muhammad. As for the contradictory ahadith, he states under the heading of 'Meat acquired by hunting for a pilgrim': "if there are two contradictory reports from the Prophet (SAW), an investigation should be made to establish what his companions have adopted". He wrote in his letter to the people of Mecca "I have disclosed wherever there was too much weakness in regard to any tradition in my collection. But if I happen to leave a Hadith without any comment, it should be considered as sound, albeit some of them are more authentic than others". Hadith Mursal (a tradition in which a companion is omitted and a successor narrates directly from Muhammad) has also been a matter of discussion among the traditionists. Abu Dawood states in his letter to the people of Mecca: "if a Musnad Hadith (uninterrupted tradition) is not contrary to a Mursal or a Musnad Hadith is not found, then the Mursal Hadith will be accepted though it would not be considered as strong as a Muttasil Hadith (uninterrupted chain)".

The traditions in Sunan Abu Dawood are divided in three categories. The first category consists of those traditions that are mentioned by Bukhari and/or Muslim. The second type of traditions are those which fulfil the conditions of Bukhari or Muslim. At this juncture, it should be remembered that Bukhari said, "I only included in my book Sahih Bukhari authentic traditions, and left out many more authentic ones than these to avoid unnecessary length".

Abu Dawood collected 500,000 hadith, but included only 4,800 in this collection. Sunnis regard this collection as fourth in strength of their six major hadith collections. It took Abu Dawod 20 years to collect the hadiths. He made a series of journeys to meet most of the foremost traditionists of his time and acquired from them the most reliable hadiths, quoting sources through which it reached him. Since the author collected hadiths which no one had ever assembled together, his sunan has been accepted as a standard work by scholars from many parts of the Islamic world[66, p.39], especially after Ibn alQaisarani's inclusion of it in the formal canonization of the six major collections[70, p.26; 69, p.36; 68, p.69].

Sunan Abu Dawood has been translated into numerous languages. The Australian Islamic Library has collected 11 commentaries on this book in Arabic, Urdu and Indonesian [71, p.36].

Al-Hafidh Abu'l-Fadl Al-Maqdisi said: "I heard Al-Imam Abu Isma' il 'Abdullah bin Muhammad AlAnsari in Harrah - when Abu 'Isa At-Tirmidhi and his book was mentioned before him - saying: "To me, his book is more useful than the books of Al-Bukhari and that of Muslim. This is because only an expert can arrive at the benefit of the books of Al-Bukhari and Muslim, whereas in the case of the book of Abu 'Isa, 


\begin{tabular}{llllll} 
& ISRA (India) $=\mathbf{3 . 1 1 7}$ & SIS (USA) $=\mathbf{0 . 9 1 2}$ & ICV (Poland) & $\mathbf{= 6 . 6 3 0}$ \\
Impact Factor: & ISI (Dubai, UAE) $=\mathbf{0 . 8 2 9}$ & PUHЦ (Russia) $=\mathbf{0 . 1 5 6}$ & PIF (India) & $=\mathbf{1 . 9 4 0}$ \\
& GIF (Australia) $=\mathbf{0 . 5 6 4}$ & ESJI (KZ) & $\mathbf{8 . 7 1 6}$ & IBI (India) & $=\mathbf{4 . 2 6 0}$ \\
& JIF & $\mathbf{1 . 5 0 0}$ & SJIF (Morocco) $=\mathbf{5 . 6 6 7}$ & OAJI (USA) & $\mathbf{0 . 3 5 0}$ \\
\hline
\end{tabular}

every one of the people can attain its benefit [72, p.52]."

Ibn Al-Athir said: "(It) is the best of books, having the most benefit, the best organization, with the least repetition. It contains what others do not; like mention of the different views, angles of argument, and clarifying the circumstances of the hadith as being sahih, da'if, or gharib, as well as disparaging and endorsing remarks (regarding narrators).

Sunnis regard this collection as fifth in strength of their six major hadith collections [73, p.69] Of the four Sunan books, al-Tirmidhi's alone is divided into four categories. The first, those hadith definitively classified as authentic, he is in agreement with Bukhari and Muslim. The second category are those hadith which conform to the standard of the three scholars, al-Tirmidhi, al-Nasa'i and Abu Dawood, at a level less than Bukhari and Muslim. Third, are the hadith collected due to a contradiction; in this case, he clarifies its flaw. And fourth, those hadith which some fiqh specialists have acted upon[74, p.97]

It is related by Abdullah bin Masud that Muhammad said, "A faithful believer neither attacks with his tongue nor utters a curse nor speaks ill of anyone nor calls names." From Tirmidhi

Aridhat al-Ahwathi bi Sharh Sunan alTirmidhi written Ibn al-Arabi d. 543H (1148-49 CE)

1. Sharh Jaami' al-Tirmidhi of which only the last portion of remains - Sharh 'Ilal at-Tirmidhi by Ibn Rajab

2. Commentary on al-Tirmidhi's Hadith Collection by al-Zayn al-Iraqi

3. Footnotes, including explanation and verification, of approximately the first third of the Sunan by Ahmad Muhammad Shakir

4. al-'Urf al Shadhi Sharh Sunan AlTirmidhi by Anwar Shah Kashmiri

5. Tuhfat Al-Ahwadhi Bi Sharh Jami ${ }^{`}$ AlTirmidhi by 'Abd al-Rahman al-Mubarkafuri, ed. 'Abd al-Rahman Muhammad 'Uthman, 10 vols., Beirut

6. Fuyoodh Un Nabi, Sharh Jami Al Tirmidhi (in Urdu Language) by 'Allama Mufti Muhammad Arshad ul Qadri', Taleem wo Tarbiyat Publisher, Lahore, Pakistan [74, p.68].

\section{Al-Sunan al-Sughra}

Al-Sunan al-Sughra is one of the Kutub alSittah (six major hadiths), and was collected by AlNasa'i[75, p.36]. Sunnis regard this collection as the fifth most important of their six major Hadith collections[2, p.63]. Al-Mujtaba (English: the selected) has about 5,270 hadiths, including repeated narrations, which the author selected from his larger work, As-Sunan al-Kubra. Among those who have written commentaries on this hadith collection are: Kitab al-Sunan al-Kubra al- 1[75, p.69].

\section{Sunan Ibn Mājah}

Sunan Ibn Mājah is one of the six major Sunni hadith collections (Kutub al-Sittah). The Sunan was authored by Ibn Mājah (b. 209/824, d. 273/887). It contains over 4,000 ahādīth in 32 books (kutub) divided into 1,500 chapters (abwāb). About 20 of the traditions it contains were later declared to be forged; such as those dealing with the merits of individuals, tribes or towns, including Ibn Mājah's home town of Qazwin.

Sunnis regard this collection as sixth in terms of authenticity of their Six major Hadith collections [76, p.5.]. Although Ibn Mājah related hadith from scholars across the eastern Islamic world, neither he nor his Sunan were well known outside of his native region of northwestern Iran until the 5th/11th century[77, p.36]. Muḥammad ibn Țāhir al-Maqdisī (d. 507/1113) remarked that while Ibn Mājah's Sunan was well regarded in Rayy, it was not widely known among the broader community of Muslim jurists outside of Iran [78, p.54]. It was also Muhammad b. Țāhir who first proposed a six-book canon of the most authentic Sunni hadith collections in his Shurūt al-a'imma al-sitta, which included Ibn Mājah's Sunan alongside Sahih Bukhari, Sahih Muslim, Sunan Abu Dawud, Sunan Nasai, and Jami al-Tirmidhi. Nonetheless, consensus among Sunni scholars concerning this six-book canon, which included Ibn Mājah's Sunan, did not occur until the 7th/13th century, and even then this consensus was largely contained to the Sunni scholarly community in the eastern Islamic world. Scholars such as alNawawi (d. 676/1277) and Ibn Khaldun (d. 808/1405) excluded Sunan Ibn Mājah from their lists of canonical Sunni hadith collections, while others replaced it with either the Muwatța' of Imām Mālik or with the Sunan ad-Dārimī. It was not until Ibn alQaisarani's formal standardization of the Sunni hadith cannon into six books that Ibn Majah's collection was regarded the esteem granted to the five other books[80, p.33; 79, p.73].

\section{Conclusion}

The collection of Abu Abdulla Muhammad ibn Isma'il al-Bukhari is the most highly regarded work of hadith literature. Bukhari is the most highly regareded work of hadith literature. Bukhari's compilation includes all known traditions of Muhammad's life considered to be authentic. There are 7,275 ahadith, some rather similar to others, which he say he refined out of 600,000 sayings that were prima facie hadith in terms of the different schools of law, usefully showing how the different schools tend to prioritize different hadith. Muslim ibn al-Hajjaj also was loath to enter into the legal debate personally, but collected the hadith that would be useful to others involved in the law. The latter would then have 


\begin{tabular}{llllll} 
& ISRA (India) $=\mathbf{3 . 1 1 7}$ & SIS (USA) $=\mathbf{0 . 9 1 2}$ & ICV (Poland) & $\mathbf{= 6 . 6 3 0}$ \\
Impact Factor: & ISI (Dubai, UAE) $=\mathbf{0 . 8 2 9}$ & PUHЦ (Russia) $=\mathbf{0 . 1 5 6}$ & PIF (India) & $=\mathbf{1 . 9 4 0}$ \\
& GIF (Australia) $=\mathbf{0 . 5 6 4}$ & ESJI (KZ) & $\mathbf{8 . 7 1 6}$ & IBI (India) & $=\mathbf{4 . 2 6 0}$ \\
& JIF & $\mathbf{1 . 5 0 0}$ & SJIF (Morocco) $=\mathbf{5 . 6 6 7}$ & OAJI (USA) & $\mathbf{0 . 3 5 0}$ \\
\hline
\end{tabular}

available to them a range of authentic sayings that could help guide them in their legal work nevertheless resulted in each one being considered one of the Musannaf, th collections in which the traditions were grouped under specific topical headings (as opposed to the Musnad works, which concentrated on grouping them under their earliest transmitters). Muslim records most of the hadith found in Bukhari's the latter placed parallel versions of the same tradition under various point of law, Muslim put them all together under their own topical headings. The former made the traditions fit his subject-matter of the traditions. The main difference is the absence of the paragraph headings characteric opf Bukhari.

Muslim's work is arranged according to fiqh(jurisprudential categories), but he does not follow his plan scrupulously: thus while Bukhari often arranges the same tradition with a different isnad under different paragraphs more than one point of law and custom, Muslim places the parallel versions together. While Bukhari's compilation is considered the more reliable of the two, Muslim's arrangement of his material has been recognized as superior, and rightly so. While Bukhari made the traditions in his collection testify to his own schedule of various point of law, Muslim left them to speak for themselves.

The remaining four works are called sunan (the word has the meaning "path" or "way") because they concentrate on the example of Muhammad's actions and decrees insofar as these provide the ultimate foundation of all Islamix law. The works recognized as the best of these collections is the Sahihs but also includes traditions are regarded as weak and suspect, he was aware of the problem and was careful to distinguish between sound and weak hadith in his text. Abu Dawud did his the material at his disposal. Unlike al-Bukhari and Muslim, he includes material that is not very reliable, or even considered actually unsound, but he does not fail to draw attention to it. Two collections very similar to Abu Dawud's are the sunan works of al-Tirmidhi and al-Nasa'i. The former is called a Jami'(collection) because it cover not only legal traditions but also, like Bukhari and Muslim, historical and other hadith as well. Nevertheless Tirimidhi confined himself to traditions on which the principles of Islamic law had already been based and did not venture to record such as might lead to new interpretation. His collection is therefore primareily a reference work as well.

The sunan of al-Nasa'I is very comprehensive. Unlike Tirmidhi he did not limit himself to recording individual hadith as a resource work for issues concerning the jurists of his day but sought to catalogue all the variant editions of each hadith knowto him, just as Muslim had done before him. His work accordingly has a place of its own in the hertage of the tradition literature.

Al-Nasa'i's main object was only to establish the text of traditions and the differences between their various versions-almost all of which he quotes at length, instead of only referring to them as Abu Dawud and al-Tirmidhi had done.

The last work, the sunan of Ibn Maja, is regarded as the weakest of all the six major works of hadith literature and some traditionists prefer the sunun of alDarimi to it. Nonetheless, although a great many authorities have openly declared some of the traditions found in this collection to be forged, it has established itself among the approved works. The other scholar, such as Abu Dawud and Tirmdhi, also recorded weak ahadith, but they mostly noted them in their books, whereas Ibn Maja, even when he recorded a false hadith, went on to use it.

\section{References:}

1. Goldziher, I. (1889-1890). Muslim Studies. 2. Halle. p. 240. ISBN 0-202-30778-6.

2. Lucas, S. C. (2004). Constructive Critics, Hadīth Literature, and the Articulation of Sunnī Islam. (p. 106.). Leiden: Brill Publishers.

3. Ibn Khallikan (n.d.). Ibn Khallikan's Biographical Dictionary. 3. Translated by William McGuckin de Slane. (p.5). Paris: Oriental Translation Fund of Great Britain and Ireland.

4. (n.d.). Jump up to: ${ }^{\mathbf{a}} \underline{\mathbf{b}}$ Tahir al-Jazairi. توجيه النظر. p. 153 .
5. (n.d.). "Various Issues About Hadiths". Abc.se. 2010-06-26.

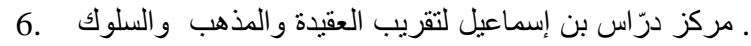
9 May 2014.

7. Ibn Hajar al-'Asqalani (2003). al-Nukat 'Ala Kitab ibn al-Salah. 1 (2nd ed.). (p.153). Ajman, U.A.E.: Maktabah al-Furqan.

8. Nasr, S. H. (1975). "The religious sciences". In R. N. Frye (Eds.). Cambridge History of Iran. Cambridge University Press. 


\begin{tabular}{llllll} 
& ISRA (India) $=\mathbf{3 . 1 1 7}$ & SIS (USA) & $=\mathbf{0 . 9 1 2}$ & ICV (Poland) & $=\mathbf{6 . 6 3 0}$ \\
Impact Factor: & ISI (Dubai, UAE) $=\mathbf{0 . 8 2 9}$ & PUHL (Russia) $=\mathbf{0 . 1 5 6}$ & PIF (India) & $=\mathbf{1 . 9 4 0}$ \\
& GIF (Australia) $=\mathbf{0 . 5 6 4}$ & ESJI (KZ) & $=\mathbf{8 . 7 1 6}$ & IBI (India) & $=\mathbf{4 . 2 6 0}$ \\
& JIF & $\mathbf{1 . 5 0 0}$ & SJIF (Morocco) $=\mathbf{5 . 6 6 7}$ & OAJI (USA) & $\mathbf{0 . 3 5 0}$ \\
\hline
\end{tabular}

9. (n.d.). "Malik ibn Anas ibn Malik ibn 'Amr, alImam, Abu 'Abd Allah al-Humyari al-Asbahi alMadani". Sunnah.org. 2010-04-10.

10. (n.d.). Mabadi Tadabbur-i-Hadith, Amin Ahsan Islahi

11. (n.d.). Harold G. Koenig, Saad Al Shohaib Health and Well-Being in Islamic Societies: Background, Research, and ApplicationsSpringer 2014 ISBN 978-3-31905873-3 page 30

12. (n.d.). "Meaning of sahih". IslamicDictionary.com. Archived from the original on February 10, 2010. 2010-05-13.

13. (n.d.). Jump up to:Muqaddimah Ibn al-Salah, pg. 160-9 Dar al-Ma'aarif edition Hadyi al-Sari, pg. 10.

14. (n.d.). Jump up to: ${ }^{\mathbf{a} b}$ A.C. Brown, Jonathan (2009). Hadith: Muhammad's Legacy in the Medieval and Modern World (Foundations of Islam series). Oneworld Publications. p. 32. ISBN 978-1851686636.

15. (n.d.). Abridged from Hady al-Sari, the introduction to Fath al-Bari, by Ibn Hajr, pg. 89 Dar al-Salaam edition.

16. (n.d.). "Al Imam Bukhari". Ummah.net. Archived from the original on 2010-02-19. 2010-02-03.

17. (n.d.). Mabadi Tadabbur-i-Hadith, Amin Ahsan Islahi

18. (n.d.). See Tareekh at-Turaath by Fu'aad Sizkeen (1/228). ^ Hady al-Sari, p. 684.

19. (n.d.). Tadhkirat al-huffaz, vol. 2 pgs. 104-5, alKutub al-'Ilmiyyahedition.

20. (n.d.). "Sahih al-Bukhari 7099". Retrieved 12 November 2016. Narrated Abu Bakr: During the battle of Al-Jamal, Allah benefited me with a Word (I heard from the Prophet). When the Prophet heard the news that the people of the Persia had made the daughter of Khosrau their Queen (ruler), he said, "Never will succeed such a nation as makes a woman their ruler.

21. Lamia Rustum Shehadeh (2003). The Idea of Women in Fundamentalist Islam. University Press of Florida. p. 229. ISBN 9780813031354.

22. Mohammad Omar Farooq (2011). Toward Our Reformation: From Legalism to Value-Oriented Islamic Law and Jurisprudence. International Institute of Islamic Thought. p. 12930. ISBN 9781565643710.

23. Hassan Affi, \& Ahmed Affi (2014). Contemporary Interpretation of Islamic Law. Troubador Publishing Ltd. pp. 14951. ISBN 9781783067596.

24. Charles Kurzman (1998). Kurzman, Charles (ed.). Liberal Islam: A Source Book. Oxford University Press. p. 123. ISBN 9780195116229.
25. (1976). Leslie, Charles Miller, (Eds.). Asian Medical Systems: A Comparative Study (reprint ed.). (pp. 57-58). University of California Press. ISBN 9780520035119.

26. (2017). "Sahih al-Bukhari 6227". 1 April 2017. Narrated Abu Huraira: The Prophet (嫩) said, "Allah created Adam in His picture, sixty cubits (about 30 meters) in height. When He created him, He said (to him), "Go and greet that group of angels sitting there, and listen what they will say in reply to you, for that will be your greeting and the greeting of your offspring." Adam (went and) said, 'As-Salamu alaikum (Peace be upon you).' They replied, 'AsSalamu'Alaika wa Rahmatullah (Peace and Allah's Mercy be on you) So they increased 'Wa Rahmatullah' The Prophet (so whoever will enter Paradise, will be of the shape and picture of Adam Since then the creation of Adam's (offspring) (i.e. stature of human beings is being diminished continuously) to the present time."

27. (1998). Islam and the Modern Age, Volume 29. Islam and the Modern Age Society. p. 39. The hadith, reported by al-Bukhari, to the effect that Adam's height was sixty cubits, has been criticised by Ibn Hajar on the basis of archaeological measurements of the homesteads of some ancient peoples, which show that their inhabitants were not of an abnormal height.

28. (n.d.). Hady al-Sari, p. 654.

29. (n.d.). Nuzhah al-Nathr, p. 154.

30. (n.d.). "An Overview of Ten Manuscripts of Șahīḥ al-Bukhārī"

31. (n.d.). Shaykh Syed Ahmad Raza Bijnori. "Anwaar ul Bari - 19 Volumes - By Shaykh Syed Ahmad Raza Bijnori"- via Internet Archive.

32. (n.d.). "Dars E Nizami Dora E Hadees 8th Year". Retrieved 2019, from archive.org.

33. (n.d.). "Dars E Nizami Dora E Hadees 8th Year". Retrieved 2019, from archive.org

34. (n.d.). "Dars e Nizami Books Online - Collection 7". Retrieved 2019, from archive.org.

35. (n.d.). "Dars e Nizami Books Online - Collection 7". Retrieved 2019, from archive.org.

36. Gibb, H. A. R., Kramers, J. H., Levi-Provencal, E., \& Schacht, J. (1986). [1st. pub. 1960]. Encyclopaedia of Islam (New Edition). Volume I (A-B). (p. 1297). Leiden, Netherlands: Brill. ISBN 9004081143.

37. Abdal-Hakim, M. (2010). "Abdal-Hakim Murad - Contentions 8". Retrieved 2010-05-13, from. www.Masud.co.uk

38. Lewis, B., Menage, V. L., Pellat, C., \& Schacht, J. (1997). [1st. pub. 1978]. Encyclopaedia of Islam (New Edition). Volume IV (Iran-Kha). 


\begin{tabular}{llllll} 
& ISRA (India) $=\mathbf{3 . 1 1 7}$ & SIS (USA) & $=\mathbf{0 . 9 1 2}$ & ICV (Poland) & $=\mathbf{6 . 6 3 0}$ \\
Impact Factor: & ISI (Dubai, UAE) $=\mathbf{0 . 8 2 9}$ & PUHL (Russia) $=\mathbf{0 . 1 5 6}$ & PIF (India) & $=\mathbf{1 . 9 4 0}$ \\
& GIF (Australia) $=\mathbf{0 . 5 6 4}$ & ESJI (KZ) & $=\mathbf{8 . 7 1 6}$ & IBI (India) & $=\mathbf{4 . 2 6 0}$ \\
& JIF & $\mathbf{1 . 5 0 0}$ & SJIF (Morocco) $=\mathbf{5 . 6 6 7}$ & OAJI (USA) & $\mathbf{0 . 3 5 0}$ \\
\hline
\end{tabular}

(p. 736). Leiden, Netherlands: Brill. ISBN 9004078193.

39. Allama Ayni (n.d). "Umdat Ul Qari" - via Internet Archive.

40. (2006). "Int". 10 October 2006. Archived from the original on 10 October 2006.

41. (n.d.). Allama Anwar Shah Kashmiri. "Faiz Ul Bari" - via Internet Archive.

42. (n.d.). "Dars E Nizami Dora E Hadees 8th Year". Retrieved 2019, from www.archive.org

43. (n.d.). Jump up to: $:^{\mathbf{b}}$ "Anak Pendang Sekeluarga: Kanzul Mutawari Dan Sumbangan Maulana Muhammad Zakariyya Kandhalawi rah". Retrieved 2015-10-10, from www.wirapendang.blogspot.my

44. (n.d.). Jump up to: ${ }^{\mathbf{a}}$ www. besturdubooks.wordpress.com. "Al Abwab Wat Tarajim Li Sahihul Bukhari" - via Internet Archive.

45. (n.d.). "The Translation of the Meanings of Sahih Al-Bukhari - Arabic-English (9 Volumes)".

46. (2012). "Translation of Sahih Bukhari". Usc.edu. Archived from the original on 201210-01. Retrieved 2010-09-26.

47. (n.d.). "Sahih Bukhari - Multiple languages". Australian Islamic Library.

48. (2015). "Sahih Muslim (7 Vol. Set)". 05 September 2015. Archived from the original on 1 June 2009.

49. Brown, A. C. J. (2014). Misquoting Muhammad: The Challenge and Choices of Interpreting the Prophet's Legacy. (p. 257). Oneworld Publications. ISBN 978-1780744209. [...] the Sahihayn, the two authentic Hadith compilations of Bukhari and Muslim bin Hajjaj that Sunni Islam has long declared the most reliable books after the Qur'an. islamicdictionary retrieved 10:06, 26 April 2010.

50. (n.d.). The number of authentic hadiths (Arabic), Muhammad Amin, May 22, 2006.

51. (n.d.). Various Issues About Hadiths

52. الإمام مسلم ومنهجه في .د. محمد عبد الرحمن الطوالبة .132. عار عمار 1. 1. 132. 132.

53. Mabadi Tadabbur-i-Hadith, Amin Ahsan Islahi (1989). Australian Islamic Library,

54. Jonathan, A. C. B. (2007), The Canonization of al-Bukhārī and Muslim: The Formation and Function of the Sunn̄̄ Hadīth Canon, (p.10). Brill Publishers. ISBN 978-9004158399. Quote: "We can discern three strata of the Sunni hadith canon. The perennial core has been the Sahihayn. Beyond these two foundational classics, some fourth/tenth-century scholars refer to a four-book selection that adds the two Sunans of Abu Dawood (d. 275/889) and alNasa'i (d. 303/915). The Five Book canon, which is first noted in the sixth/twelfth century, incorporates the Jami' of al-Tirmidhi (d. 279/892). Finally the Six Book canon, which hails from the same period, adds either the Sunan of Ibn Majah (d. 273/887), the Sunan of alDaraqutni (d. 385/995) or the Muwatta' of Malik b. Anas (d. 179/796). Later hadith compendia often included other collections as well.' None of these books, however, has enjoyed the esteem of al-Bukhari's and Muslim's works."

55. (n.d.). "Various Issues About Hadiths". Retrieved 2019, from www.abc.se

56. (n.d.). Ignác Goldziher, Muslim Studies, vol. 2, pg. 240. Halle, 1889-1890. ISBN 0-202-307786

57. Scott, C. L. (2004). Constructive Critics, Hadīth Literature, and the Articulation of Sunnī Islam, (p. 106). Leiden: Brill Publishers.

58. (n.d.). Ibn Khallikan's Biographical Dictionary, translated by William McGuckin de Slane. Paris: Oriental Translation Fund of Great Britain and Ireland. Sold by Institut de France and Royal Library of Belgium. Vol. 3, p. 5.

59. (n.d.). "Sunan Abu Dawood". AUSTRALIAN ISLAMIC LIBRARY.

60. Jonathan A. C. B. (2007). The Canonization of al-Bukhārī and Muslim: The Formation and Function of the Sunnī Hadīth Canon, p.10. Brill Publishers. ISBN 978-9004158399. Quote: "We can discern three strata of the Sunni hadith canon. The perennial core has been the Sahihayn. Beyond these two foundational classics, some fourth/tenth-century scholars refer to a four-book selection that adds the two Sunans of Abu Dawud (d. 275/889) and al-Nasa'i (d. 303/915). The Five Book canon, which is first noted in the sixth/twelfth century, incorporates the Jami' of al-Tirmidhi (d. 279/892). Finally the Six Book canon, which hails from the same period, adds either the Sunan of Ibn Majah (d. 273/887), the Sunan of al-Daraqutni (d. 385/995) or the Muwatta' of Malik b. Anas (d. 179/796). Later hadith compendia often included other collections as well.' None of these books, however, has enjoyed the esteem of al-Bukhari's and Muslim's works."

61. (n.d.). Imam Tirmidhi and his Al-Jami' alSunan: http://daruliftaa.com/node/7130

62. (n.d.). "Hadith $-\mathrm{Z}$ is typing...". Retrieved 2019, from www.lifetimesandcrimes.wordpress.com

63. (n.d.). "Imam Tirmidhi and his Al-Jami' alSunan (الجامع السنن للإمام الترمذي رضي الله عنه) daruliftaa.com". Retrieved 2019, from www.daruliftaa.com

64. (n.d.). Al-Risalah al-Mustatrafah, p.11.

65. (n.d.). Shurut al-A'immah al-Sittah, by alMaqdisi, p. 101. 


\begin{tabular}{llllll} 
& ISRA (India) $=\mathbf{3 . 1 1 7}$ & SIS (USA) & $=\mathbf{0 . 9 1 2}$ & ICV (Poland) & $=\mathbf{6 . 6 3 0}$ \\
Impact Factor: & ISI (Dubai, UAE) $=\mathbf{0 . 8 2 9}$ & PUHL (Russia) $=\mathbf{0 . 1 5 6}$ & PIF (India) & $=\mathbf{1 . 9 4 0}$ \\
& GIF (Australia) $=\mathbf{0 . 5 6 4}$ & ESJI (KZ) & $=\mathbf{8 . 7 1 6}$ & IBI (India) & $=\mathbf{4 . 2 6 0}$ \\
& JIF & $\mathbf{1 . 5 0 0}$ & SJIF (Morocco) $=\mathbf{5 . 6 6 7}$ & OAJI (USA) & $\mathbf{0 . 3 5 0}$ \\
\hline
\end{tabular}

66. Haddad, G. F. (n.d.). "Various Issues About Hadiths".

67. (n.d.). Shurut al-A'immah al-Sittah, by alMaqdisi, p. 92.

68. (n.d). Archived from the original on 2016-04-20. Retrieved 2019,

from https://web.archive.org/web/2016042011 $\underline{1419 /}$

http://www.yanabi.com/index.php?\%2Ftopic\%

2F429974-the-book-launching-ceremonyfuyoodh-un-nabi-sharh-jami-al-tirmidhi\% $2 \mathrm{~F}$

69. Jonathan, A. C. B. (2007). The Canonization of al-Bukhārī and Muslim: The Formation and Function of the Sunnī Hadīth Canon, p.10. Brill Publishers. ISBN 978-9004158399. Quote: "We can discern three strata of the Sunni hadith canon. The perennial core has been the Sahihayn. Beyond these two foundational classics, some fourth/tenth-century scholars refer to a four-book selection that adds the two Sunans of Abu Dawud (d. 275/889) and al-Nasa'i (d. 303/915). The Five Book canon, which is first noted in the sixth/twelfth century, incorporates the Jami' of al-Tirmidhi (d. 279/892). Finally the Six Book canon, which hails from the same period, adds either the Sunan of Ibn Majah (d. 273/887), the Sunan of al-Daraqutni (d. 385/995) or the Muwatta' of Malik b. Anas (d. 179/796). Later hadith compendia often included other collections as well.' None of these books, however, has enjoyed the esteem of al-Bukhari's and Muslim's works."

70. (n.d.). Various Issues About Hadiths

71. (n.d.).

Retrieved 2019, from https://www.loohpress.com/product_info. php/products id/1937

72. Gibril, H. (2003, April 4). "Various Issues About Hadith". living ISLAM - Islamic Tradition.

73. Robson, J. (1958). "The Transmission of Ibn Mājah's 'Sunan"'. Journal of Semitic Studies. 3.2: 139.

74. Brown, J. (2009). "The Canonization of Ibn Mājah: Authenticity vs. Utility in the Formation of the Sunni Hadīth Canon". Revue des Mondes Musulmans et de la Méditerranée. 129: 175.

75. Goldziher, I. (1971). Muslim Studies, Volume II. Aldine Publishing Company. pp. 241-44.

76. Ignác, G. (n.d.). Muslim Studies, vol. 2, pg. 240. Halle, 1889-1890. ISBN 0-202-30778-6

77. Scott, C. L. (2004). Constructive Critics, Hadith Literature, and the Articulation of Sunnī Islam, (p.106). Leiden: Brill Publishers.

78. (n.d.). Ibn Khallikan's Biographical Dictionary, translated by William McGuckin de Slane. Paris: Oriental Translation Fund of Great Britain and Ireland. Sold by Institut de France and Royal Library of Belgium. Vol. 3, pg. 5. 